\title{
Health and Demography of Native Amazonians: Historical Perspective and Current Status
}

\author{
Warren M. Hern
}

* University of Colorado,

Os nativos da Amazônia foram vitimas de dois grandes ataques históricos: um na época da Conquista e outro durante o século $X X$. Devido a doenças epidênicas e à destruição ambiental, inumeras tribos passaram a vivenciar problemas de deslocamentos, dizintação e extinção em uma única geração. $A$ aculturação e a construção de grandes projetos desenvolvimentistas tiveram efeitos catastróficos sobre as populaçōes indigenas. Em diversos aspectos, os nativos da Amazônia sofreram uma "Transição Epidemiológica". Paradoxalmente, um dos efeitos da dilaceração cultural para alguns dos nativos da Amazônia foi a perda de controles culturais sobre a fecundidade, fazendo com que a elevada fecundidade se tornasse um importante problema de saúde. Com o rápido crescimento de populações amazônicas não indigenas, o desmatamento e a urbanização, os nativos da Amazônia enfrentam sérios obstáculos para a sua sobrevivència a longo prazo.

\section{INTRODUCTION}

On a recent excursion to Chapada dos Guimaräes to photograph Brazilian wildlife, I had the good fortune to encounter a young Boróro man who was now living near the town of that name. He offered to show me a special waterfall near his home. We descended through the brush to a beautiful scene. The falls cascaded some ten meters to a shallow pool. The young man slipped off his shorts and plunged under the waterfall. He whooped and called me to 
join him, so I did. I imitated his joyful Boróro whoop and we both roared with laughter. The water in that pristine place was cool and wonderful. It was a precious moment.

My new friend is only one generation from a tribal life in the bush. He now lives a marginal existence as an artist and day laborer with his pleasant wife, a "branca", who was pregnant and about to deliver their first child. The waterfall he loves and shared with me is in a pathetically small patch of undisturbed forest surrounded by the devastation on an advancing "civilization". The natural forest and wildlife is being replaced by cultivated crops. Pesticides and fertilizers now flow into the Brazilian Pantanal, the greatest wetland wildlife refuge in the Americas.

We sat my friend's house after a dinner of vegetables and sipped mate as we watched the moon rise. The evening air was filled with the smoke of great fires on the plains below. "Estāo matando o pulmão do mundo", he said. "First they kill us and then they kill the earth." The government would not let him return to his village, he said. He had lived away too long. His family was gone, but he wanted to be with his friends, to speak Boróro, to take part in rituals. His tribe, he said, is dying. They will soon be gone, he said.

This was a moving personal experience for me, but more than that, it seems to capture a little bit of the fate of the Amazonian Indians.

To speak of the health and biology of native Amazonians, one must first see that they are victims of two massive historical assaults, one at the time of Conquest and the other, an even more inexorable twentieth century. Many of them have been in highly isolated enclaves until the past few decades, but these have gone from contact to displacement and decimation in a generation. The ultimate enemies of the native Amazonians are the loss of their pristine environment and the loss of their unique cultures.

\section{HISTORICAL PERSPECTIVE}

The first people to enter the South American tropical lowlands probably arrived around 10,000 years ago, according to Martin (1973). Carneiro (1974) agrees with this estimate. Lathrap (1977) estimates that intensive cultivation of bitter manioc in alluvial flood plains began 
6000 to 7000 years ago, but Roosevelt $(1980,1989)$ suggests a date of $4000-5000$ BP. Lathrap (1970) especially thinks that riverine populations were relatively dense by the time of conquest. Both Lathrap and Roosevelt agree with other authors (Dobyns, 1966; Lipschutz, 1966; Denevan, 1976; Thornton, 1987; Myers, 1988) that indegenous populations collapsed following the Conquest.

Dobyns (1966) estimated a 20:1 loss of population among indigenous groups following the conquest due to the introduction of European disease, slave trading, and intertribal warfare, although Denevan (1976:212) states that a $35: 1$ ratio may be more accurate. It is not unlikely that depopulation ratios reached $50: 1$ on the basis of reports cited by Dobyns. Meggers (1971:151) states that a smallpox epidemic occurred in the lower Amazon in 1621 and reached the upper Amazon in 1651. Meggers also states that yellow fever and malaria were introduced to the South American continent following the importation of slaves from Africa. Steward and Metraux (1948) note that smallpox epidemics also occurred in 1670-80 following Western contact and decimated native populations in the upper Amazon Basin. Myers (1989) estimates a reduction of as much as $99.5 \%$ of the Omagua, Cocama, and indigenous populations of the lower Huallaga in the 150 years following European contact.

Wagley (1974a) and Chagnon and Melancon (1983) have described the catastrophic effects of depopulation on native tribes including the loss of many cultural traditions.

In studying two Brazilian tribes, the Tenetehára and Tapirapé, Wagley (1974b) noted that they had two quite different approaches to controlling fertility and natality. The Tapirapé, valuing small families with no more than three children and no more than two of the same sex, sanctioned infanticide to maintain this norm. The Tapirape also practiced postpartum sexual abstinence. Among the Tenetehára, infanticide was permitted only occasionally. Both tribes were encouraged by missionaries to have as many children as possible. Their success in dealing with the loss of population as the result of Western contact was quite different. Wagley reported that the Tenetehára were growing in numbers and that the Tapirape culture was disintegrating. Among other things, the Tapirapé social 
organization is much more vulnerable to disruption by population loss.

In addition to severe population loss in the time after European contact, native Amazonians have been subjected to unprecedented destruction of their environment since World War II with the construction of numerous highways across the Andes and across the Brazilian Amazon (Saffirio and Hames, 1983; Moran, 1983). This has been accompanied by widespread colonization and deforestation (Stearman, 1983; Hecht, 1983; Moran, 1989; Lisanskky, 1990; CNP/CIPA, 1984). Various countries, including Brazil, Bolivia, Ecuador, and Peru, have sponsored colonization of the Amazon as the partial result of population growth in other parts of those countries (Stearman, 1983:52; Bedoya, 1981; Moran, 1981:75; Whitten, 1981:5; Fearnside, 1986:7). In 1987 alone, 47 million acres were burned in Brazil, of which $40 \%$ was primary rainforest (Simons, 1988; Brown, 1989:4). Other development projects such as hydroelectric dams have destroyed or threaten to obliterate colossal areas of native Amazonian environments (Treece, 1987; Smith, 1982). Aside from the abundantly documented fact these projects have had catastrophic effects for native populations (Ramos and Taylor, 1979), the long-term implications for biodiversity and for regional and global climate change are extremely ominous (Gómez et al, 1972; Shukla et al, 1990; Tans et al, 1990).

\section{DEMOGRAPHIC STUDIES OF NATIVE AMAZONIANS}

Denevan (1976:291) estimates that $8,500,000$ indigenous people lived in Amazonia at the time of Conquest, although Mycrs (1988) estimates that there may have been as many as $10,000,000$ in parts of the upper Peruvian Amazon. Denevan estimates that, following a reduction of the Indian population to approximately 250,000 , it has increased now to around 500,000. Population nadirs probably occurred at around the end of the $19^{\text {th }}$ century. Gunter Tessman, for example, estimated that the Shipibo numbered approximately 3,000 in 1920 , whereas the Shipibo-Conibo population now numbers between 25,000 
and 40,000 (Bergman, 1981; Hern, 1988). Many tribes have become extinct; others have flourished or have absorbed others. Thorough contemporary demographic studies of Amazon Indian societies are uncommon. Studies of the Xavánte (Neel et al, 1964), Kaingang (Salzano, 1961), Yanomamo (Chagnon, 1977), and Shipibo (Hern, 1971, 1977, 1988), appear to be among the main demographic reports available until recently, but they are often not comparable. Black et al (1978) studied eight unacculturated tribes in northeast Amazonia. Flowers (1990) gives a report of repeated observations of the post-contact demography of the Xavante. An exceptionally thorough report of the Mucajai Yanomámá by Early and Peters (1990) provides one of the only longitudinal demographic studies of a single group. There are no integrating studies that give overall demographic information about all Amazonian tribes.

A principal difficulty in obtaining accurate demographic information, of course, is that Amazon tribes have not had written languages until recently, and in any case, systems of counting are often lacking. Categories of time are general and do not allow precise interpretations. The Shipibo word for "yesterday", for example (vakish), is the same as the word for "tomorrow". Moatian means "a long time ago" and serves for most reckonings of over a year. Even having birth "documents" are not certain guides to birth dates. Birth certificates are sometimes not sought immediately after a birth. Reports of dates to recording oflicials are approximate, and they may be misunderstood or recorded improperly. Owners may cheerfully change documented birth dates in order to attain certain objectives such as military induction. Stillbirths may not be counted as term births, thereby complicating the calculations of birth interval length or reproductive span. Children who have died or been killed may be lorgotten or ignored. Requests for estimates for time or dates are sometimes interpreted as entertaining opportunities for the creative imagination, not to be taken seriously. As a result, the only way it is possible to obtain some accurate demographic Jata is to live permanently with a group and observe every vital event. This, obviously, is not practical for most observers. 
Data collected by Maybury-Lewis, Salzano, Chagnon, Neel, and Peters in connection with ethnographic and genetic studies are among the most detailed demographic reports.

Neel and Salzano (1970) found that one group of Xavánte had a Mean Completed Fertility of 5.7 and speculated that the Xavánte practiced postpartum sexual abstinence in order to control fertility. Neel and Chagnon (1968) found an overall Mean Completed Fertility for the Xavánte of 3.6 and 3.2 for the Yanomámá. They described these numbers as "unbelievably low" and suspected that births resulting in infanticide are not reported as live births. The result is one live birth every 4.4 years for the Xavánte and one every 6.6 years for the Yanomamo. Both the Xavánte and Yanomamo (Chagnon, 1977) practice sororal polygyny, with a $50 \%$ polygyny rate among Yanomamo males. Mean age for the Xavánte is 18 ; mean age for the Yanomamo is 22 . Infant mortality is $18 \%$ for the Yanomamo. Neel and Chagnon reported that the proportions of the populations under the age of fifteen for the Xavánte and Yanomámá was $39 \%$ and $32 \%$, respectively. The authors judged that both birth rates and infant-child mortality rates were lower for the Yanomámá than for the Xavánte. Salzano, Neel, and Maybury-Lewis (1967) also found that $39 \%$ of the Xavante population was under 15 years of age. Flowers (1983) found that a comparable Xavánte group was younger in 1977 , with $48.6 \%$ under the age of 15 . Mean birth intervals were 20.9 months, although for women whose babies had died, intervals were only 16.6 months. In a 1988 follow-up study, Flowers (1990) showed that, after an initial post-contact decline, fertility increased markedly among the São Domingos Xavánte. I have found exceedingly high fertility rates among the Shipibo (Hern, 1977, 1988, 1991) that appear to have been partially the result of disruption of traditional cultural patterns such as polygyny, which dampened fertility.

Neel and Weiss (1975) calculated a general fertility rate of .250 for the Yanomámá with a Net Reproduction Rate of 1.25. Yanomámá women complete a pregnancy every 3-4 years, with $85 \%$ of the births resulting in a live birth. The authors estimated annual population growth 
rates at between 0.5 and $1.0 \% .50 \%$ of the women who reach age 15 die before menopause. Childhood mortality rates have dropped considerably, but overall combined infant and child mortality, including infanticide, stood at about $50 \%$ at the time of the report.

Early and Peters (1990:20) show an increase in mortality among the Mucajai Yanomámá in the two years immediately preceding contact compared with lower mortality in the two years before that with general diminution of death rates and population increase in post-contact years. Even with data from 28 years of observation by Peters, the authors could not reach firm conclusions concerning changes in longevity following contact (Early and Peters, 1990:73, Table 7.2).

In a study of the health status of Kayapó Indians, Ayres and Salzano (1972) found that $48.4 \%$ of the population was under 15 years of age. In an earlier study of the Kaingang, Salzano (1961) found that $35.7 \%$ of the population was under 15 , whereas $54.5 \%$ of a mestizo population was under 15 .

Neel (1970) reports a $15-20 \%$ infanticide rate for primitive tribes in the Amazon, with weaning at 3 years for Yanomamo. Polygyny provides an important device for natural selection, according to Neel. Polygyny is common throughout South American tropical forest societies (Siskind, 1973), although its effects on fertility are not well documented.

Goldman (1979) observed among Kubéu that women are not eager to bear children. Kubéu women had knowledge of abortifacients and acknowledge performing infanticide. An unwanted child is buried alive on the spot where it is born. Childbirth is considered a dangerous period. Sexual abstinence is practiced by both parents for. one year.

Infanticide is practiced among the Munduruku in the cases of twins and congenital birth defects (Murphy and Murphy, 1974: 166).

Larrick (1979) reports a high incidence of infanticide and stillbirth among the Waorani of Ecuador, who otherwise appear to be quite healthy. 
Devereaux (1955) reported use of "imi rau" among "Kashinaia" [Kaxináwa] as a contraceptive and as an abortifacient. The Jivaro of Ecuador used "sacha mangue". The words "imi rau" as reported by Devereaux are virtually identical to the Shipibo words jimi "blood" and rao "medicine". Johnston and Kensiger (1969; 1971) found a $27 \%$ polygyny rate among the Kaxináwa, a Panoan tribe, and noted that the medicine man proscribed the use of either modern or herbal contraceptives. A conscious decision to cease using abortifacients has contributed to a high fertility rate. Also, the practice of infanticide is not observed to the same degree as before. This tribal "population policy" was reported to have been a response to a declining population seen as the result of Western contact and an epidemic in 1951. The effective fertility ratio for the Kaxináwa was 113.5 compared to 96.3 for the Hutterites (Smith, 1960).

Siskind (1973) observes that the Sharanahua, also a Panoan group, have abortions in order to have three-year birth intervals. The Sharanahua have three ways of making women scarce: through limited sexual access, polygyny, and female infanticide.

Bugos and MacCarthy (1984) cite the example of the Ayoreo of southwestern Bolivia, who practice infanticide. The Ayoreo tolal lertility rate is 6.185 ; infanticide lowered it to 4.02. The strength of the authors' conclusions are diminished by the fact that women who did not practice infanticide were excluded from the sample.

Early and Petcrs (1990:76) report that both induced abortion and infanticide are practiced among the Mucajai Yanomamo, and infanticide may account for as much as $44 \%$ of all inlant deaths.

Holmberg (1985) reports that Siriono women observe a one-month period of postpartum sexual abstinence.

A comparison of various demographic indices in different tribes is shown in Table I. 
ANÁLISE
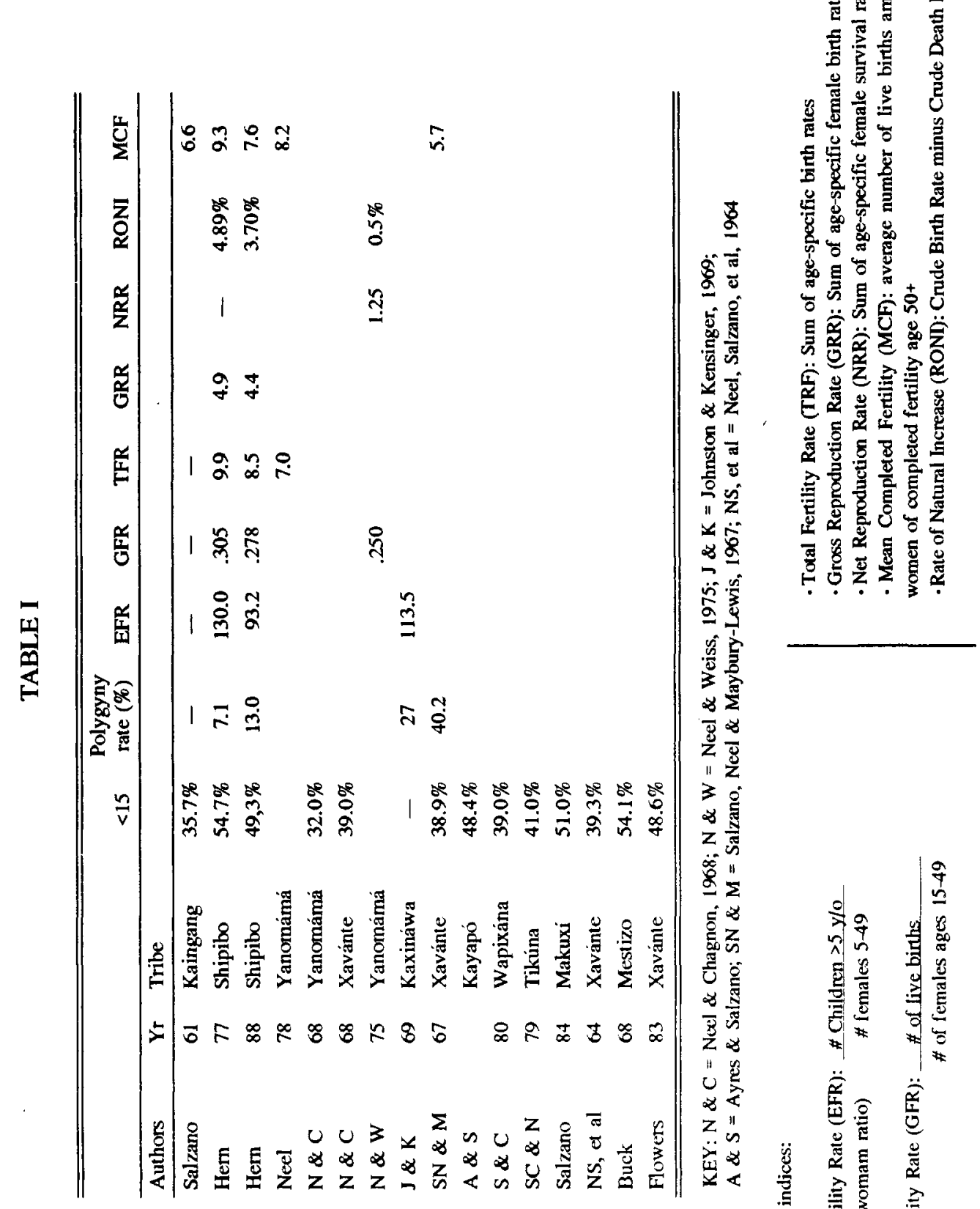
One interpretation of Table $I$ is to note that earlier studies of tribal groups showed lower proportions of individuals under 15 years of age, whereas later studies (Salzano, 1984; Flowers, 1983) shower higher proportions of approximately $50 \%$. The earlier studies, with the $0-15$ age group under $40 \%$, may be correlated with higher rates of polygyny (compare Salzano, Neel, and Maybury-Lewis, 1967 , with Hern, 1977). While these studies are not strictly comparable, it appears that acculturation (or deculturation, as the case might be), is associated with higher fertility and a younger population.

Generalizing from these sparse data is hazardous, but it seems that following a catastrophic depopulation in the first 400 years following Western contact, at least some Amazonian populations are experiencing high fertility and rapid population growth, whereas others have become extinct or nearly so. It remains to be seen whether those experiencing rapid population growth can maintain their traditional cultures in any respect.

In many ways, native Amazonians have experienced a reversal of the "epidemiologic transition" described by Omran (1971). Whereas Omran's theory begins with an "Age of Pestilence and Famine" and proceeds to an "Age of Receding Pandemics" and thence to an "Age of Degenerative and Man-made Disease", the Amazon Indians have had a mirror image of this experience since European contact. Roosevelt (1989) and Greene (1986) describe few except chronic diseases in Marajó skeletons, which preceded European contact. The pandemics began when the Europeans arrived. Coimbra (1989), in describing the health effects of disruptions of social networks and substistence patterns among the Surui, shows that the group is expcriencing all three phases of the "epidemiologic transition" at once.

\section{HEALTH STATUS OF NATIVE AMAZONIANS}

Our information about the health status of early Amazonians is almost nonexistent except for some skeletal remains found at Marajó (Roosevelt, 1989). There is evidence that tuberculosis, hookworm, Trypanosoma cruzi, and treponemal diseases were present in prehistoric South 
American populations (Allison, 1973; Coimbra, 1988; Baker \& Armelagos, 1988; Hackett, 1963; Cockburn, 1961; Allison et al, 1974). However, most of the evidence for these diseases comes from West coast archeological remains, and we do not know the extent to which these diseases affected those in the lowlands. These afflictions are not reported in the Marajó individuals. In the rest of the Amazon, paleo-pathological evidence is lacking due to the unsuitable conditions for the preservation of human remains (Coimbra, 1988).

We must surmise a fundamentally vigorous and ingenious aboriginal population, however, which survived in a exceedingly complex and hostile environment by identifying a wide variety of food, technical, and medicinal resources (Berlin \& Berlin, 1978; Dufour, 1987; Posey, 1983; Tournon, 1984; Hern, 1976; Milton, 1984; Ross, 1978; Behrens, 1981; Pollock, 1988). The simple fact is that Amazon societies, however vigorous and complex, were overwhelmed by the introduction of Old World diseases and Europeans aggression. Black (1990) asserts that the severe impact of epidemic disease introduced from the Old World was due both to social disruption and to genetic isolation.

\section{INTRODUCED DISEASES}

\section{Measles (rubeola)}

Black et al (1982) states that the measles virus probably did not exist at the time the Western Hemisphere was populated across the Bering land bridge, and probably dit not even exist at the time of European contact. His basis for this assertion is that Amazonian tribes having first contact typically display no evidence of exposure to the measles antigen, nor do they have antibodies to many other common viral disease agents. The antibody response of Ameridians to measles vaccination is essentially the same, if somewhat more symptomatic, as other populations, indicating no genetic immunodeficiency in this regard (Neel, Centerwall et al, 1970; Black et al, 1982; Black et al, 1970; Black et al, 1974). 


\section{Smallpox (Variola major)}

Smallpox has been a great killer in Amazonia since the time of Conquest. From the time of the first reported epidemic of smallpox in 1621 (Meggers, 1971) until the last in 1964 (personal observartion), smallpox probably killed millions of native Amazonians. Working as a medical student in the upper Peruvian Amazon in 1964, I encountered numerous cases of smallpox in what was the last epidemic in the Western Hemisphere. Most of the several hundred Shipibo and mestizos whom I vaccinated had never previously been vaccinated. Throughout the region, virtually $100 \%$ of the populations of whole native villages were afflicted with high mortality rates (R. Eichenberger, personal communication). Thornton et al (1991) have shown that native American populations may have had variable recovery rates following decimation by epidemics such as smallpox.

\section{Tuberculosis}

Tuberculosis has been endemic in the Americas since prehistoric times, and there is a high incidence of the diseases among contemporary Amerindian populations (Clark et al 1987). The introduction of tuberculosis into the Amazon is fairly recent (Black, 1975), but it is the main health problem in many native Amazonian groups today (Flowers, 1983; Black et al, 1974). Clark speculates that the current epidemic may stem from either exposure to more virulent strains of Mycobacterium tuberculosis or environmental change leading to a loss of exposure to natural vaccination, presumably when Amazonians were separated from their hemispheric ancestors. The widespread Amazonian practice of communal eating and drinking has unquestionably contributed to the epidemic spread of tuberculosis. In the Peruvian Amazon, in particular, the preparation of masato from masticated manioc is a popular and probably deadly custom in this regard.

\section{Yellow fever}

Cockbum (1961b) stated that the principal vector of 
yellow fever, Aedes aegypti, has probably been in South America for only 400 years. Black found high frequencies of antibodies to arboviruses, including yellow fever, among three Carib and four Kayapó Indian villages (Black et al, 1974), indicating prolonged exposure to these agents.

\section{Chaga's Disease and Leishmaniasis}

Cutaneous and mucocutaneous leishmaniasis is widespread throughout the upper Peruvian Amazon basin (personal observation), but documentation of the distribution of these diseases in Amazonia is sparse. Coimbra (1988) notes that Trypanosoma cruzi are found in Chilean mummies dating from 470 b.C. and that both the organism and its vector, the triatomina insect, are found throughout the Amazon basin. In spite of this long history in the Americas and wide distribution in the Amazon basin, according to Coimbra, the number of autochtonous parasitic infections is small among native Amazonians by comparison with other populations. Coimbra attributes the low Chaga's disease infection rate to the high human mobility and small settlement size of Amazon Indians. Chaga's disease is a serious potential threat to native Amazonian populations, however, as development and urbanization permits the domiciliation of triatomines.

In Coimbra's view, mobility is of adaptative value among preindustrial Amazon populations and minimizes contamination of surroundings with pathogens. Also, he notes that animal domestication was not generally practiced until recently.

\section{Onchocerciasis}

Microfilaria are found in various Amazon Indian groups (Lawrence et al, 1979; Beaver et al, 1976; Lawrence et al, 1980) and exposure to onchocerciasis has been found in Ecuador (Guderian et al, 1987) and Brazil (Moraes et al, 1974). While clinical manifestations of the disease have not yet become widespread (Salzano \& Neel, 1976), it is only a matter of time before this severely debilitating disease affects large numbers of native Amazonians. 


\section{Schistosomiasis}

Schistosomiasis has become widespread throughout the hemisphere but has not yet become in the Amazon. It is endemic in Northeastern Brazil (Lee, 1985:69), and it threatens to become a major health problem for Amazonians. The Amazon habitat is highly suitable for the spread of schistosomiasis, especially if large dams are constructed in the region.

\section{Helminthiasis}

Infection with multiple species of intestinal parasites is the rule in relatively undisturbed Amerindian tribes, according to Lawrence (Lawrence et al, 1980). When native Amazonians become sedentary, however, they may be at higher risk of clinically important parasite burdens. Chernela and Thatcher (1989) found that the nomadic Máku had ascaris infection rates as low as $34 \%$, whereas the 75 to $100 \%$ of sedentary Tukáno were infected. Schwaner and Dixon (1974) found that hookworm egg counts were six times higher in a sedentary unacculturated Tukúna Indians and among a mixed Tukúna-mestizo population living in a more urbanized settlement.

\section{Chronic Diseases}

The incidence of cardiovascular disease has not been found to be high in native Amazonian populations. Weinstein, Neel, and Salzano found that chronic and degenerative diseases were rare in a population of Xavánte Indians, and that blood pressures were generally low (1976), a result replicated by Ayres and Salzano in the Kayapó (1972). Both Oliver (Oliver et al 1975) and Larrick et al (1982) found that blood pressures did not increase with age among the Yanomámá and Waorani, respectively. Both groups of investigators attributed the low blood pressure levels to low dietary salt levels. Glanville and Geerdink made the same observation earlier in the Trio and Wayaná tribes (1970). Lowenstein (1961) found that unacculturated Karajás Indians had lower blood 
pressures than sedentary Munduruku, and that the Munduruki experienced blood pressure increases with age. Tenbrinck (1964) found lower blood pressures among Peruvian Amazon Indians of different tribes tham among Mestizos from the same region. Nowaczynski et al (1985), stydying relationships between blood pressure and serum aldosterone levels, determined that the salt-free diet of the Yanomámá gave them higher aldosterone and lower blood pressure levels by comparison with the more acculturated Guaymi Indians of Panama. Fleming-Moran and Coimbra (1990) found that the lifestyles of lowland South American Indians include many protective factors against hypertension, but these conditions are rapidly changing and native Amazonians are being exposed to more stress.

Obesity is uncommon in native Amazonians; Glanville and Geerdink found that skinfold thickness among the Tiriyó and Wayána tribes remains constant throughout life (Glanville and Geerdink, 1976).

Diabetes is virtually unknown among native Amazonians. In their study of two tribes in Brazil, the Yanomámá and Marúbo, Spielman et al, found that the less acculturated group, the Yanomámá, showed no significant rise in one-hour blood glucose levels characteristic of glucose-intolerant North American control subjects (1982).

Donnely et al (1977) found that dental deterioration was positively associated with exposure to Western culture.

\section{Violent and Accidental Death}

In their study of the Waorani, Larrick et al (1982) found that $4 \%$ of all deaths were due to snakebite. While I have not calculated cause-specific death rates among the Shipibo, I have observed an increasing proportion of deaths due to accidental gunshot wounds, homicide, and vehicular accidents since 1964. Reports of children drowning and dying from falls are common among the Shipibo.

Intervillage and intertribal warface has been an important cause of mortality for Amazonian tribes in the past, and Chagnon (1988) reports that $30 \%$ of all adult male deaths among the Yanomámá are due to violence.

Infanticide is still practiced in some Amazonian tribes, 
but its significance as a major cause of death appears to have diminished, especially in the past century.

\section{CURRENT HEALTH STATUS}

In their general assessment of health and physical status of the Xavánte, Weinstein, Neel, and Salzano recorded their impression of "exuberant health and vitality" among the children and adult males, but premature aging in the women (emphasis supplied). Larrick et al, made the same observations concerning the Waorani (1982). Black found the nutritional status of Brazilian Kayapó Indians to be generally good (Black et al, 1977). Kayapó infants were small but gained with age. Moran notes that no survey has ever noted signs of protein deficiency among autochthonous South Americans in their native habitats (Moran 1981:207). In fact, protein intake is frequently higher than minimum daily requirements. Bergman observed that the Shipibo consume up to 75 grams of protein per day (Bergman, 1980). Chagnon and Hames (1979) found that the Yanomamo consume approximately the same amount of protein per day.

Flowers (1983) observed that the Xavante people she studied in 1977 were in generally good health, although tuberculosis was a major health problem. She recorded a $27 \%$ mortality rate up to the age of 2 , with most deaths occurring as the result of respiratory diseases.

In a study of the nutritional status of Indian children in the Alto Xingu region, Fagundes-Neto et al. found that $96 \%$ of the children were well nourished and only $3 \%$ were malnourished (1981). Height was normal for $84.8 \%$. By contrast, $54 \%$ of the children in low-income urban families were malnourished. In tribal life, food was available and equally distributed, fertility control was practiced, and there was an absence of socioeconomic unevenness. This was offset by the presence of endemic malaria.

Hodge and Dufour (1991) found that high infant mortality rates and growth retardation among Shipibo children may be the result of an interaction of suboptimal nutrition and infectious discases.

While nutrition assessment is critical to evaluation of 
general health, an extended discussion of the nutritional status of native Amazonians is not included in this chapter since it is thoroughly reviewed by Darna Dufour elsewhere in this volume (Dufour, 1991).

In my own studies of the Shipibo, I have found them to be in excellent health but extremely vulnerable to tuberculosis and the acute infectious diseases of childhood (Hern, 1971). The infant mortality rate of 97.5 per 1000 live births that I reported in 1977 is minimal (Hern, 1977), since subsequent studies have shown infant mortality rates up to $50 \%$ (Hern, 1988). The vast majority of Shipibo infant and child deaths are due to acute gastrointestinal and respitatory diseases. Infant and child gastrointestinal diseases are facilitated by the ubiquitous fecal contamination of water and food in spite of almost obsessive Shipibo cleanliness. Neonatal tetanus is a major cause of neonatal death for Shipibo and other Amazonian tribes, which generally have no immunologic experience with the tetanus antigen (Black et al, 1974).

A major cause of death for Shipibo women is cervical cancer, owing, I think, to a combination of high fertility, lack of male circumcision, and the desperate use of caustic substances for contraception (Hern, 1976). Women also experience significant mortality associated with childbirth, although actual rates of maternal mortality have not been established for native Amazonian women. The early onset of childbearing and high fertility over a prolonged period undoubtedly contributes to the "premature aging" of women noted by Weinstein and others. The discouragement of polygyny by missionaries has resulted in shorter birth intervals and higher individual fertility for Indian women (Hern, 1988). The consequences are inimical to the health of both women and their children.

\section{CONCLUSION}

In the future, the health and wealfare of native Amazonians will affected by numerous external factors over which they have little or not control. Among the most important of these, aside of the lack of access to the same level of health care afforded to other national populations, will be the environmental policies of national governments. 
Salzano (1990) points out that these include the construction of colossal dams for hydroelectric energy, as in Brazil, that destroy the environments necessary for the survival of indigenous groups. Another is the seemingly inexorable highway construction, colonization, and deforestation that accompanies the expansion of other populations.

Pucallpa, which was probably an aboriginal Shipibo settlement, had no more than three thousand inhabitants in 1943. These had arrived at about the time the first trans-Andes highway in Peru was pushed through to the Ucayali River. By 1964, when I made my first trip to the Peruvian Amazon, $P$ ucallpa's population was estimated at 25,000 . There were dirt streets and Saturday night gunfights. The Shipibo were displaced and treated as sub-humans. By 1984, the population os Pucallpa was estimated at between 125,000 and 200,000 . That is at least a $5,000 \%$ increase in 40 years. Mestizo fisherman from $P$ ucallpa now regularly exploit Ucayali waters some 200 kilometers from Pucallpa in areas previously fished exclusively by Shipibo and a few local mestizos. Aramburu estimates that the annual population growth rate of the upper Peruvian Amazon basin has been between 4 and 5\% per year between 1940 and 1981 (Aramburu, 1982:16), and it may be as much as $10 \%$ including immigration (personal communication).

The aboriginal environment of the native Amazonians is shrinking rapidly and under great pressure from outside sources of development and exploitation. A significant factor in this is that the populations of nearly all Amazon Basin countries are growing at rates from 3 to 4\% (World Resources Institute, 1987). By the year 2000, the Amazon Basin countries will add at least the following numbers to their populations (from 1990):

\begin{tabular}{|c|c|c|c|}
\hline Brazil & & 28. & Million \\
\hline Bolivia & ………… & 2. & Million \\
\hline Columbia & ………...... & 5.5 & Million \\
\hline Ecuador & ………..... & 3. & Million \\
\hline Guyana & … & 0.9 & Million \\
\hline Peru & …………... & 5. & Million \\
\hline Suriname & 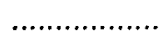 & 0.1 & Million \\
\hline Venezucla & …………...... & 4. & Million \\
\hline
\end{tabular}


The countries that ring the Amazon Basin will add the equivalent of half the current population of Mexico or roughly twice the current population of Canada over the next 10 years (Zachariah \& Vu, 1988). Population pressure from outside is likely to have an enormous destructive effect on the Amazon environment and its native inhabitants. Combined with accelerating deforestation and urbanization (Merrick, 1986: 25), it means that much of the Amazon will have been transformed within 100 years from a sparsely settled wilderness rainforest with tiny, isolated settlements of indigenous inhabitants to a scrub desert interrupted by rapidly growing cities.

There is nothing in the history of the human species to prepare us or our native Amazonian friends for this experience.

Native Amazonians have been the victims of two massive historical assaults, one at the time of the Conquest and the other during the Twentieth century. Due to epidemic disease and environmental destruction, many tribes have gone from contact to displacement, decimation, and extinction in a single generation. Deculturation and the construction of large development projects have had catastrophic effects on native populations. In many ways, native Amazonians have experienced a reverse of the "Epidemiologic Transition". Paradoxically, one of the effects of cultural disruption for some native Amazonians has been the loss of cultural controls on fertility with the result that high fertility has become a major health problem. Combined with rapid growth of non-indigenous Amazonian populations, deforestation, and urbanization, native Amazonians face grave obstacles to long-term survival.

\section{REFERENCES}

ALLISON, M. J.; MENDONZA, D. \& PEZIE, K. A. - Documentation of a case of tuberculosis in Pre-Columbian America. American Review of Respiratory Disease, 107: 985-991, 1975. 
ALLISON, M. J.; PEZZIA, A.; HASEGAWA, I. \& GERSZTEN, E. - A case of hookworm infestation in a Pre-Columbian American. American Journal of Physical Anthropology, 41: 103-106, 1974.

ARAMBURÚ, C. E. - Expansión de la frontera agraria y demográfica de la selva alta peruana. In: Colonización en la Amazonía (C.E. Aramburu, org.), Ediciones CIPA, Lima, 1982.

AYRES, M. \& SALZANO, F. M. - Health status of the Brazilian Cayapo Indians. Tropical and Geographical Medicine, 24: 178-185, 1972.

BAKER, B. J. \& ARMELAGOS, G. J. - The origin and antiquity of syphilis. Current Anthropology, 29: 703-737, 1988.

BECKERMAN, S. - The abundance of protein in Amazonia: A reply to Gross. American Anthropologist, 81: 533-560, 1979.

BEAVER, P. C.; NEEL, J. V. \& ORIVEL, T. C. - Dipetalonema perstans and Mansonella ozzardi in Indians of Southem Venezuela. American Journal of Tropical Medicine and Hygiene, 25: 263-265, 1976.

BEDOYA, E. - La destrucción del Equilibrio Ecológico en las Cooperativas del Alto Huallaga. Serie Documento 1, Ediciones CIPA, Lima, 1981.

BEHRENS, C. - Time allocation and meat procurement among the Shipibo Indians of Eastern Peru. Human Ecology, 9: 189-220, 1981.

BERGMAN, R. - Amazon Economics: The Simplicity of Shipibo Indian Wealth. University Microfilms International, Ann Arbor, Michigan, 1980.

BERLIN, B. \& BERLIN, E. - Etnobiología, subsisténcia, y nutrición en una sociedad de la selva tropical: Los Aguaruna (Jíbaro). In: Salud y Nutrición en Sociedades Nativas (A. Chiriff, org.), pp. 13-47, Centro de Investigación y Promoción Amazónica, Lima, 1978.

BLACK, F. L. - Infectious diseases in primitive societies. Science, 187: 515-518, 1975.

BLACK, F. L; WOODALL, J. P.; EVANS, A. S.; LIEBHABER, H. \& HENLE, G. - Prevalence of antibody against viruses in the Tiriyo, an isolated Amazon tribe. American Journal of Epidemiology, 91: 430-438, 1970.

BLACK, F. L.; HIERHOLZER, W. J.; PINHEIRO, F. P.; EVANS, A. S.; WOODALL, J. P.; OPTON, E. M.; EMMONS, J.E.; WEST, B. S.; EDSALL, G.; DOWNS, W. G. \& WALLACE, G. D. - Evidence for persistence of infectious agents in isolated human populations. American Journal of Epidemiology, 100: 230-250, 1974. 
BLACK, F. L.; HIERHOLZER, W. J.; BLACK, D. P.; LAMM, S. H. \& LOCAS, L. - Nutritional status of Brazilian Kayapó Indians. Human Biology, 49: 139-153, 1977.

BLACK, F. L.; PINHEIRO, F. P.; OLIVA, O.; HIERHOLZER, W. J.; LEE, R. V.; BRILLER, J. E. \& RICHARDS, V. A. Birth and survival patterns in numerically unstable proto agricultural societies in the Brazilian Amazon. Medical Anthropology, 2: 95-127, 1978.

BLACK, F. L.; HIERHOLZER, W. J.; LIAN-CHEN, J. F.; BERMAN, L. L. GABBAY, Y. \& PINHEIRO, F. P. Genetic correlates of enhanced measles susceptibility in Amazon Indians. Medical Anthropology, 6: 37-46, 1982.

BROWN, L. R.; FLAVIN, C. \& POSTEL, S. - A world at risk In: State of the World, 1989 (L. R. Brown, eds.), pp. 4, WW Norton Co., New York, 1989.

BUGOS, P. E. \& McCARTHY, L. M. - Ayoreo infanticide: A case study. In: Infanticide: Comparative and Evolutionary Perspectives (G. Hausfater \& S. B. Hrdy, eds.), pp. 503-520, Aldine, New York, 1984.

BUCK, A. A.; SASAKI, T. T. \& ANDERSON, R. I. - Health and Disease in Four Peruvian Villages. Johns Hopkins Press, Baltimore, 1968.

CARNEIRO, R. L. \& HILSE, D. F. - On determining the probable rate of population growth during the Neolithic. American Anthropologist, 68: 177-181, 1966.

CARNEIRO, R. L. - The transition from hunting to horticulture in the Amazon Basin. In: Man in Adaptation: The Cultural Present (Y. A. Cohen, ed.), $2^{\text {od }}$ Ed., pp. 131-144, Aldine, Chicago, 1974.

CHAGNON, N. A. - Studying the Yanomamo. Holt, Rinehart, and Winston, New York, 1974.

Yanomamo: The Fierce People. $2^{\text {nd }}$ Ed., Holt, Rinehart, and Winston, New York, 1977. Yanomamo: The Fierce People. $3^{\text {rd }}$ Ed., Holt, Rinehart, and Winston, New York, 1983.

Life histories, blood revenge, and warfare in a tribal population. Science, 239: 985-992, 1988.

CHAGNON, N. A. \& HAMES, R. B. - Protein deficiency and tribal warfare in Amazonia: New data. Science, 203: 910913, 1979.

CHAGNON, N. A. ; FLINN, M. V. \& MELANCON, T. F. - Sex-ratio variation among the Yanomamo Indians. In: Evolutionary Biology and Human Social Behavior: An Anthropological Perspective (N.A. Chagnon \& W. Irons, eds.), pp. 290-320, Duxbury Press, North Scituate, 1979. 
CHAGNON, N. A. \& MELANCON, T. F. - Epidemics in a tribal population. Cultural Survival Occasional Paper, 11: 53-78, 1983.

Reproduction, numbers of kin and epidemics in tribal populations: A case study. In: Population and Biology (N. Keyfitz, eds.), Ordina Editions, Liege, Belgium, 1984.

CHERNELA, J. M. \& THATCHER, V. E. - Comparison of parasite burdens in two native Amazonian populations. Medical Anthropology, 10: 279-285, 1989.

CLARK, G. A.; KELLEY, M. A.; GRANGE, J. M. \& HILL, M. C. - The evolution of mycobacterial disease in human populations: A reevaluation. Current Anthropology, 28: 4562, 1987.

COCKBURN, T. A. - The origin of treponematoses. Bulletin of the World Health Organization, 24: 221-228, 1961.

Eradication of infectious diseases. Science, 133: 1050-1058, 1961.

Infectious diseases in ancient populations. Current Anthropology, 12: 45-62, 1971.

COIMBRA, C. E. A. Jr. - Human settlements, demographic pattern, and epidemiology in lowland Amazonia: The case of Chagas's disease. American Anthropologist, 90: 82-97, 1988.

From Shifting Cultivation to Coffee Farming: The Impact of Change on the Health and Ecology of the Surui Indians in The Brazilian Amazon. Ph.D. Dissertation, Bloomington, Department of Anthropology, Indiana University (E.U.A.), 1989.

COLCHESTER, M. (ed.) - The Health and Survival of the Venezuelan Yanomama. International Workgroup for Indigenous Affairs. Document No. 53, Copenhagen, 1985.

CNP/CIPA - Población y Colonización en la Alta Amazonia Peruana. Consejo Nacional de Población/Centro de Investi gación y Promoción Amazónica, Lima, 1984.

DENEVAN, W. M. - Epilogue. In: The Native Population in the Americas in 1492 (W. M. Denevan, ed.), pp. 289-292, University of Winsconsin Press, Madison, 1976.

DEVEREUX, G. - A Study of Abortion in Primitive Societies. Julian, New York, 1955.

DOBYNS, H. F. - Estimating Aboriginal American population: An appraisal of techniques with a new hemispheric estimate. Current Anthropology, 7: 395-416, 1966.

DONNELLY, C. J.; THOMPSON, L. A.; STILES, H. M.; BREWER, C.; NEEL, J. V. \& BRUNELLE, J. A. - Plaque, caries, periodontal diseases, and acculturation among Yanomamo Indians, Venezuela. Journal of Community Dental and Oral Epidemiology, 5: 30-39, 1977. 
DUFOUR, D. L. - Nutrition in the Northwest Amazon: Household dietary intake and time-energy expenditures. In: Adaptive Responses of Native Amazonians (R. B. Hames \& W. T. Vickers, ed.), pp. 329-355, Academic Press, New York, 1983.

Insects as food: A case study from the Northwest Amazon. American Anthropologist, 89: 383-397, 1987.

Diet and Nutritional Status of Amerindians: A Review of the Literature. Cadernos de Saúde Pública, 7: 481-502, 1991.

EARLY, J. D. \& PETERS, J. F. - The population dynamics of the Mucajai Yanomama. Academis Press, New York, 1990.

FAGUNDES-NETO, U.; BARUZZI, R. G.; WEHBA, J.; SIVESTRINI, W. S.; MORAIS, M. B. \& CAINELLI, M. Observations of the Alto Xingu Indians (Central Brazil) with special reference to the nutritional evaluation of children. American Journal of Clinical Nutrition, 34: 2229-2235, 1981.

FEARNSIDE, P. M. - Human Carrying Capacity of the Brazilian Rainforest. Columbia University Press, New York, 1986.

FLEMING-MORAN, M. \& COIMBRA JR., C. E. A. - Blood ressure studies among Amazonian Native populations: $A$ review from an epidemiological perspective. Social Science and Medicine, 31: 593-601, 1990.

FLOWERS, N. M. - Seasonal factors in subsistence, nutrition, and child growth in a Central Brazilian Indian community. In: Adaptive Responses of Native Amazonians (R. B. Hames \& W. T. Vickers, eds.), pp. 357-390, Academic Press, New York, 1983.

Contact and demographic change: The Xavante case. Paper presented at the 59th Annual Meeting of the American Association of Physical Anthropologists, Miami, Florida, April 4-7, 1990.

GLANVILLE, E. \& GEERDINK, R. - Skinfold thickness, body measurements and age changes in Trio and Wajana Indians of Surinam. American Journal of Physical Anthropology, 32: 455-461, 1970.

Boold pressure of Amerindians from Surinam. American Journal of Physical Anthropology, 37: 251-254, 1972.

GOLDMAN, I. - The Cubeo: Indians of the Northwest Antazon. $2^{\text {at }}$ Ed., University of Illinois Press, Urbana, Illinois, 1979.

GÓMEZ-POMPA, A.; VAZQUEZ-YANES, C. \& GUEVARA, S. The tropical rainforest: A nonrenewable resource. Science, 177: 762-765, 1972. 
GREENE, D. - Assessment of the state of preservation of human skeletal remains from Marajo Island, Pará, Brazih and the potential for Marajoara cemetery excavation. Unpublished report submitted to the National Science Foundation, Washington, 1986.

GUDERIAN, R. H.; MACKENZIE, C. D. \& PROANO, J. R. Onchocerciasis in Ecuador: Absence of microfilaremia. Journal of Tropical Medicine and Hygiene, 90: 213-214, 1987.

HACKETT, C. J. - On the origin of the human treponematoses. Bulletin of the World Health Organization, 29: 7-41, 1963.

HAMES, R. B. \& VICKERS, W. T. (eds.) - Adaptive Responses of Native Amazonians. Academic Press, New York, 1983.

HECHT, S. - Cattle ranching in the Eastern Amazon: Environmental and social implications. In: The Dilemma of Amazonian Development (E. F. Moran, ed.), pp. 155-188, Westview Press, Boulder, Colorado, 1983.

HERN, W. M. - Community Health, Fertility Trends, and Ecocultural Change in a Peruvian Amazon Indian Village: 1964-1969. Master of Public Health Thesis, University of North Carolina School of Public Health, Chapel Hill, 1971.

Knowledge and use of herbal contraceptives in a Peruvian Amazon village. Human Organization, 35: 9-19, 1976.

High fertility in a Peruvian Amazon Indian village. Human Ecology, 5: 355-367, 1977.

Polygyny and Fertility Among the Shipibo: An Epidemiologic Test of an Ethnographic Hypothesis. Ph.D. Disssertation, University of North Carolina School of Public Health, Chapel Hill, 1988.

Polygyny and fertility among the Shipibo of the Peruvian Amazon. Population Studies (In Press), 1991.

HOLMBERG, A. R:- Nomads of the Long Bow: The Sirionó of Eastern Bolivia. Waveland Press, Prospect Heights, Illinois, 1969.

JOHNSTON, F. E. \& KEMSINGER, K. M. - Fertility and mortality differentials and their implications for microevolutionary change among the Cashinahua. Human Biology, 43: 356-364, 1971.

JOHNSTON, F. E.; KENSINGER, K. M.; JANTZ, R. L. \& WALKER, G. F. - The population structure of the Peruvian Cashinahua: Demographic, genetic and cultural interrelationships. Human Biology, 41: 29-41, 1969.

LARRICK, J.; YOST, J.; KAPLAN, J.; KING, G. \& MAYHALL, J. - Patterns of health and disease among the Waorani Indians of Eastern Ecuador. Medical Anthropology, 3: 147$189,1979$. 
LATHRAP, D. W. - The "hunting" economies of the tropical rain forest zone of South America: An attempt at historical perspective. In: Man the Hunter (R.B. Lee \& I. DeVore, eds.), Aldine, Chicago, 1968.

The Upper Amazon. Praeger, New York, 1970.

Our father the cayman, our mother the gourd. In: The

Origins of Agriculture (C. A. Reed, ed.), Mouton, The Hague, 1977.

LAWRENCE, D.N.; ERDTMANN, B.; PEET, J. W.; NEEL, J. V. \& SALZANO, F. M. - Epidemiologic studies among Amerindian populations of Amazonia. II. Prevalence of Mansonella ozzardi. American Journal of Tropical Medicine and Hygiene, 28: 991-996, 1979.

Estudos epidemiológicos entre populações indígenas da Amazônia. II. Prevalências de microfilaremia de Mansonella ozzardi: Comparação de dois métodos de diagnóstico. Acta Amazonica, 10: 763-769, 1980.

LAWRENCE, D.N.; NEEL, J.V.; ABADIE, S.H.; MOORE, L.L. \& KAGAN, I. G. - Epidemiologic studies among Amerindian populations of Amazonia. III. Intestinal Parasitoses in newly contacted and acculturating villages. American Journal of Tropical Medicine an Hygiene, 29: 530-537, 1980.

LEE, J. A. - The Environment, Public Health, and Human Ecology: Considerations for Economic Development. The Johns Hopkins Press, for the World Bank, Baltimore, 1985.

LEWIS, T. H. \& BRANNON, W. L. - Poliomyelitis in an isolated Amerindian population. Journal of the American Medical Association, 230: 1295-1297, 1974.

LIPSCHUTZ, A. - La despoblación de las Indias despues de la conquista. America Indigena, 26: 229-247, 1966.

LISANSKY, J. - Migrants to Amazonia: Spontaneous Colonization in the Brazilian Frontier. Westview Press, Boulder, Colorado, 1990.

LOWENSTEIN, F. W. - Blood pressure in relation to age and sex in the tropics and subtropics. Lancet, $i: 389-392,1961$.

LYON, P. J. (ed.) - Native South Americans: Ethnology of the Least Known Continent. Waveland Press, Prospect Heights, Illinois, 1985.

MARTIN, P. S. - The discovery of America. Science, 197: 969 974, 1973. 
MEGGERS, B. J. - Amazonia: Man and Culture in a Counterfeit Paradise. AMH Publishing Corporation, Arlington Heights, Illinois, 1971.

MERRICK, T. W. - Population pressure in Latin America. Population Bulletin, 14: 1-50, 1986.

MILTON, K. - Protein and carbohydrate resources of the Maku Indians of Northwest Amazonia. American Anthropologist, 86: 7-27, 1984.

MORAES, M. A. P. \& CHAVES, G. M. - Onchocerciasis in Brazil: New findings among the Yanomama Indians. Bulletin of the Pan American Health Organization, 8: 95-99, 1974.

MORAN, E. F. - Developing the Amazon. Indiana University Press, Bloomington, Indiana, 1981.

(ed.) - The Dilemma of Amazonian Development. Westview Press, Boulder, Colorado, 1983.

MORSE, D. - Prehistoric tuberculosis in America. American Review of Respiratory Disease, 83: 489-504, 1961.

MURPHY, Y. \& MURPHY, R. F. - Women of the Forest. Columbia University Press, New York, 1974.

MYERS, T. P. - El efecto de pestilencia sobre las poblaciones de la Amazonia superior. Amazonia Peruana, 15: 61-82, 1988.

NEEL, J. V. - Lessons from a "primitive" people. Science, 170: 815-822, 1970.

Infectious disease among Amerindians. Medical Anthropology, 6: 47-55, 1982.

Health and disease in unacculturated Amerindian populations. In: Health and Disease in Tribal Societies (K. Elliot \& J. Whelan, eds.), pp. 159-177, Elsevier, Amsterdam, 1977.

The population structure of an Amerindian tribe, the Yanomama. Annual Review of Genetics, 12: 365-413, 1978.

NEEL, J. V.; CENTERWALL, W. R.; CHAGNON, N. A. \& CASEY, H. L. - Notes on the effect of measles and measles vaccine in a virgin-soil population of South American Indians. American Journal of Epidemiology, 91: 418-429, 1970.

NEEL, J. V. \& CHAGNON, N. A. - The demography of two tribes of primitive, relatively unacculturated South American Indians. Proceedings of the National Academy of Sciences, 59: 680-689, 1968. 
NEEL, J. V. \& SALZANO, F. M. - Further studies on the Xavante Indians. $X$. Some hypothesis-generalizations resulting from these studies. American Journal of Human Genetics, 19: 554-574, 1970.

NEEL, J. V.; SALZANO, F. M.; JUNQUEIRA, P. C.; KEITER, F. \& MAYBURY-LEWIS, D. - Studies on the Xavante Indians of the Brazilian Mato Grosso. Human Genetics, 16: 52-140, 1964.

NEEL, J. V. \& WEISS, K. M. - The genetic structure of a tribal population, the Yanomama Indians. XII. Biodemographic studies. American Journal of Physical Anthropology, 42: 25$52,1975$.

NOWACZYNSKI, W.; OLIVER, W. J. \& NEEL, J. V. - Serum aldosterone and protein-binding variables in Yanomama Indians: A 'non-salt' culture as compared to partially acculturated Guaymi Indians. Clinical Physiology and Biochemestry, 3: 289-306, 1985.

OLIVER, W. J.; COHEN, E. L. \& NEEL, J. V. - Blood pressure, sodium intake, and sodium related hormones in the Yanomamo Indians, a "non-salt" culture. Circulation, 52: 146-151, 1975.

OMRAN, A. R. - The epidemiologic transition. Milbank Memorial Fund Quarterly, 49: 509-538, 1971.

POLLOCK, D. K. - Health care among the Culina, Western Amazonia. Cultural Survival Quarterly, 12: 28-32, 1988.

POSEY, D. A. - Indigenous ecological knowledge and development of the Amazon. In: The Dilemma of Amazonian Development (E. F. Moran, ed.), pp. 225-257, Westview Press, Boulder, Colorado, 1983.

ROOSEVELT, A. C. - Parmana: Prehistoric Maize and Manioc Subsistence Along the Amazon and Orinoco. Academic Press, New York, 1980.

Natural resource management in Amazonia before the conquest: Beyond ethnographic projection. In: Natural Resource management by Folk and Indigenous Societies in Amazonia (D. Posey \& W. Balle, eds.), Advances in Economic Botany No. 7, pp. 30-62, New York Botanical Garden, New York, 1989.

ROSS, E. B. - Food taboos, diet, and hunting strategy: The adaptation to animals in Amazon cultural ecology. Current Anthropology, 19: 1-36,1978. 
SALZANO, F. M. - Demography of the Caingang Indians. Human Biology, 33: 110-130, 1961.

Changing patterns of disease among South American Indians. In: Diseases of Complex Etiology in Small Populations: Ethnich Differences and Research Approaches (R. Chakraborty \& E. J. E. Szathmary, eds.), pp. 301-323, Alan R. Liss, New York, 1985.

SALZANO, F. M. \& CALlEGARI-JACQUES, S. M. - Demographic and genetic relationships among Brazilian Wapishana Indians. Annals of Human Biology, 7: 129-138, 1980.

South American Indians: A Case Study in Evolution. Clarendon Press, Oxford, 1988.

SALZANO, F.M.; CALLEGARI-JACQUES, S.M. \& NEEL, J.V. Demografia genética dos índios Ticuna da Amazônia. Acta Amazonica, 9: 517-527, 1979.

SALZANO, F. M. \& NEEL, J. V. - New data on the vision of South American Indians. Bulletin of the Pan American Health Organization, 10: 1-8, 1976.

SALZANO, F. M.; NEEL, J. V. \& MAYBURY-LEWIS, D. Further studies on the Xavante Indians. I. Demographic data on two additional villages: Genetic structure of the tribe. American Journal of Human Genetics, 19: 463-489, 1967.

SAFFIRIO, J. \& HAMES, R. - The forest and the highway. Cultural Survival Occasional Paper, 11: 1-52, 1983.

SHUKLA, J;; NOBRE, C. \& SELLERS, P. - Amazon deforestation and climate change. Science, 247: 1322-1325, 1990.

SCHWANER, T. D. \& DIXON, C. F. - Helminthiasis as a measure of cultural change in the Amazon Basin. Biotropica, 6: 32-37, 1974.

SISKIND, J. - Tropical forest hunters and the economy of sex. In: Peoples and Cultures of Native South America (D. R. Gross, ed.), pp. 226-240, The Natural History Press, Garden City, New York, 1973.

SIMONS, M. - Amazon settlers turn forest to ash in name of progress. The New York Times, October 11, New York, 1988.

SMITH, R. C. - The dialectics of domination in Peru: Native communities and the myth of the vast Amazonian emptiness. Cultural Survival Occasional Paper, vol. 8, 1982.

SMITH, T. E. - The Cocos-Keelin Islands: A demographic laboratory. Population Studies, 14: 94-130, 1960.

SPIELMAN, R.S. - Glucose tolerance in two unacculturated Indian tribes of Brazil. Diabetologia, 23: 90-93, 1982. 
STEARMAN, A. M. - Forest to pasture: Frontier settlement in the Bolivian lowlands. In: The Dilemma of Amazonian Development (E. F. Moran, ed.), pp. 51-64, Westview Press, Boulder, Colorado, 1983.

The Yuquí connection: Another look at Sirionó deculturation. American Anthropologist, 86: 630-650, 1984.

STEWARD, J. H. - The native population of South America. In: Handbook of South American Indians (J. H. Steard, ed.), vol. 6, Bulletin of the Bureau of American Ethnology No. 143, U.S. Government Printing Office, Washington, D.C., 1949.

STEWARD, J. H. \& METRAUX, A. - Tribes of the Peruvian and Ecuadorian Montaña. In: Handbook of South American Indians (J. H. Steward, ed.), vol. 3, pp. 51-59, 290-347, Bulletin of the Bureau of American Ethnology No. 143, U.S. Government Printing Office, Washington, D.C., 1948.

TANS, P. P.; FUNG, I. Y. \& TAKAHASHI, T. - Observational constraints on the global atmospheric $\mathrm{CO}_{2}$ budget. Science, 247: 1431-1438, 1990.

RAMOS, A. R. \& TAYLOR, K. I. - The Yanomama in Brazil, 1979. IWGIA Document No. 37, ARC/IWGLA/Survival International, Copenhagen, 1979.

TEESMAN, G. - Menschen olme Gott. Ein Besuch bei den Indianen des Ucayali. Stuttgart, 1928.

THORNTON, R. - American Indian Holocaust and Survival: $A$ Population History Since 1492. University of Oklahoma Press, Norman, Oklahoma, 1987.

TOURNON, J. - Investigaciones sobre las plantas medicinales de los Shipibo-Conibo del Ucayali. Amazonia Peruana, i: 91 $118,1984$.

TREECE, D. - Bound in Mistery and Iron: The Impact of the Grande Carajás Programme on the Indians of Brazil. Survival International, London, 1987.

VICKERS, W. T. - Development and Amazonian Indians: The Aguarico case and some general principles. In: The Dilemma of Amazonian Development (E. F. Moran, ed.), pp: 25-50, Westview Press, Boulder, Colorado, 1983.

WAGLEY, C. - Cultural influences on population: A comparison of two Tupi tribes. In: Environment and Cultural Behavior (A. P. Vayda, ed.), pp. 268-282, The Natural History Press, Garden City, New York, 1969. (ed.) - Man in the Amazon. University of Florida Press, Gainesville, Florida, 1973.

Welcome of Tears: The Tapirapé Indians of Brazil. Waveland Press, Prospect Heights, Illinois, 1977. 
The effects of depopulation upon social organization as illustrated by the Tapirapé Indians. In: Native South Americans: Ethnology of the Least Known Continent (P. J. Lyons, ed.), pp. 373-376, Waveland Press, Prospects Heights, Ilinois, 1975.

WEINSTEIN, E. D.; NEEL, J. V. \& SALZANO, F. M. - Further studies on the Xavante Indians. VI. The physical status of the Xavante of Simōes Lopes. American Journal of Human Genetics, 19: 532-542, 1981.

WHITTEN, N. E. - Introduction. In: Cultural Transformations and Ethnicity in Modern Ecuador (N. E. Whitten, ed.), University of Illinois Press, Urbana, Illinois, 1981.

WORLD RESOURCES INSTITUTE - World Resources 1987. Basic Books, New York, 1987.

ZACHARIAH, K. C. \& VU, M. T. - World Population Projections, 1987-88 Edition: Short- and Long-Term Estimates. Johns Hopkins Press for the World Bank, Baltimore, 1988. 